\title{
Epitaxial Growth and Bandgap Control of Ni1-xMgxO Thin Film Grown by Mist Chemical Vapor Deposition Method
}

\section{AUTHOR(S):}

Ikenoue, Takumi; Yoneya, Satoshi; Miyake, Masao; Hirato, Tetsuji

\section{CITATION:}

Ikenoue, Takumi ...[et al]. Epitaxial Growth and Bandgap Control of Ni1-xMgxO Thin Film Grown by Mist Chemical Vapor Deposition Method. MRS Advances 2020, 5(31-32): 17051712

\section{ISSUE DATE:}

2020

URL:

http://hdl.handle.net/2433/252437

\section{RIGHT:}

This article has been published in a revised form in MRS Advances http://doi.org/10.1557/adv.2020.219. This version is free to view and download for private research and study only. Not for re-distribution or re-use. (c) copyright holder.; The full-text file will be made open to the public on 21 October 2020 in accordance with publisher's 'Terms and Conditions for Self-Archiving', この論文は出版社版でありません。引用の際には出版社版をご確認ご利用ください。; This is not the published version. Please cite only the published version. 


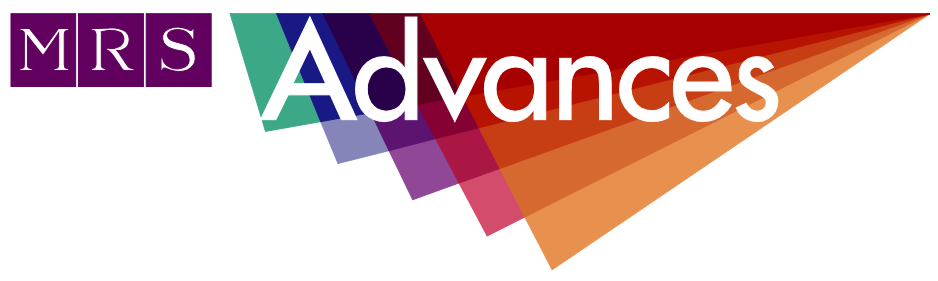

\section{Epitaxial Growth and Bandgap Control of $\mathrm{Ni}_{1-x} \mathrm{Mg}_{x} \mathrm{O}$ Thin Film Grown by Mist Chemical Vapor Deposition Method}

Takumi Ikenoue $^{1}$, Satoshi Yoneya ${ }^{1}$, Masao Miyake ${ }^{1}$, and Tetsuji Hirato ${ }^{1}$

${ }^{1}$ Graduate School of Energy Science, Kyoto University, Kyoto 606-8501, Japan

ABSTRACT

Wide-bandgap oxide semiconductors have received significant attention as they can produce devices with high output and breakdown voltage. p-Type conductivity control is essential to realize bipolar devices. Therefore, as a rare wide-bandgap p-type oxide semiconductor, $\mathrm{NiO}$ $\left(3.7 \mathrm{eV}\right.$ ) has garnered considerable attention. In view of the heterojunction device with $\mathrm{Ga}_{2} \mathrm{O}_{3}$ (4.5-5.0 eV), a p-type material with a large bandgap is desired. Herein, we report the growth of a $\mathrm{Ni}_{1-x} \mathrm{Mg}_{x} \mathrm{O}$ thin film, which has a larger bandgap than $\mathrm{NiO}$, on $\alpha-\mathrm{Al}_{2} \mathrm{O}_{3}(0001)$ substrates that was developed using the mist chemical vapor deposition method. The $\mathrm{Ni}_{1-x} \mathrm{Mg}_{x} \mathrm{O}$ thin films epitaxially grown on $\alpha-\mathrm{Al}_{2} \mathrm{O}_{3}$ substrates showed crystallographic orientation relationships identical to those of $\mathrm{NiO}$ thin films. The $\mathrm{Mg}$ composition of $\mathrm{Ni}_{1-x} \mathrm{Mg}_{x} \mathrm{O}$ was easily controlled by the $\mathrm{Mg}$ concentration of the precursor solution. The $\mathrm{Ni}_{1-x} \mathrm{Mg}_{\mathrm{x}} \mathrm{O}$ thin film with a higher $\mathrm{Mg}$ composition had a larger bandgap, and the bandgap reached $3.9 \mathrm{eV}$ with a $\mathrm{Ni}_{1-x} \mathrm{Mg}_{x} \mathrm{O}$ thin film with $x=0.28$. In contrast to an undoped $\mathrm{Ni}_{1-x} \mathrm{Mg}_{x} \mathrm{O}$ thin film showing insulating properties, the $\mathrm{Li}$-doped $\mathrm{Ni}_{1-x} \mathrm{Mg}_{x} \mathrm{O}$ thin film had resistivities of $10^{1}-10^{5} \Omega \cdot \mathrm{cm}$ depending on the Li precursor concentration, suggesting that Li effectively acts as an acceptor.

\section{INTRODUCTION}

Wide-bandgap semiconductors have attracted wide attention owing to their ability of realizing high output and high breakdown voltage power devices. The bandgaps of wide-bandgap semiconductors such as $\mathrm{GaN}(3.4 \mathrm{eV})$ and $\mathrm{Ga}_{2} \mathrm{O}_{3}(4.5-5.0 \mathrm{eV})$ have been further expanded using alloy crystals with $\mathrm{AlN}(6.3 \mathrm{eV})$ and $\mathrm{Al}_{2} \mathrm{O}_{3}(8.8 \mathrm{eV})$, respectively. Oxide semiconductors typified by $\mathrm{Ga}_{2} \mathrm{O}_{3}$ have been studied as they can obtain films under atmospheric pressure and can be expected to further increase the bandgap that directly affects device performance[1]. Although the demand for wide-bandgap oxide semiconductors is increasing, many wide-bandgap oxide semiconductors, including $\mathrm{Ga}_{2} \mathrm{O}_{3}$, 
exhibit only n-type conductivity. Therefore, as it is a rare wide-bandgap p-type oxide semiconductor, $\mathrm{NiO}(3.7 \mathrm{eV})$ has attracted increasing attention. In view of the fabrication of heterojunction devices with materials such as $\mathrm{Ga}_{2} \mathrm{O}_{3}$, the bandgap of $\mathrm{NiO}$ is slightly small (3.7 eV), and a p-type oxide semiconductor with a larger bandgap is required. Therefore, we focused on $\mathrm{Ni}_{1-x} \mathrm{Mg}_{x} \mathrm{O}$, which is a semiconductor alloy crystal comprising $\mathrm{NiO}$ and $\mathrm{MgO}$. Both $\mathrm{NiO}$ and $\mathrm{MgO}$ crystallize in the cubic rock-salt structure, and $\mathrm{Ni}_{1-}$ ${ }_{x} \mathrm{Mg}_{x} \mathrm{O}$ is stable over the entire composition range with no phase transition or significant changes in lattice parameters, with a structural mismatch of only $0.8 \%$ at maximum[2]. Therefore, potentially, the bandgap can be expanded while maintaining p-type conduction from $3.7 \mathrm{eV}$ for $\mathrm{NiO}$ to $7.8 \mathrm{eV}$ [3] for $\mathrm{MgO}$. With regard to $\mathrm{Ni}_{1-x} \mathrm{Mg}_{x} \mathrm{O}$, several studies have been conducted on epitaxial growth via vacuum processes such as molecular beam epitaxy[4] and pulsed laser deposition[5]; however, growth via the solution atmospheric pressure process is limited to polycrystalline films[6], and there have only been few studies on epitaxial growth. In previous studies, we reported the epitaxial growth of $\mathrm{NiO}$ thin films on $\alpha-\mathrm{Al}_{2} \mathrm{O}_{3}$ substrates via mist chemical vapor deposition (CVD)[7]. By this method, highquality oxide thin films can be grown at atmospheric pressure and semiconductor alloy crystals such as $\mathrm{Mg}_{\mathrm{x}} \mathrm{Zn}_{1-\mathrm{x}} \mathrm{O}[8,9]$ and $\left(\mathrm{Al}_{\mathrm{x}} \mathrm{Ga}_{1-\mathrm{x}}\right)_{2} \mathrm{O}_{3}[10]$ can be easily obtained by mixing precursor source solutions.

Herein, we report the increase in bandgap due to the alloy crystals of $\mathrm{NiO}$ with $\mathrm{MgO}$ via mist CVD by controlling the $\mathrm{Ni}$ and $\mathrm{Mg}$ concentration in the precursor solution. The $\mathrm{Mg}$ composition in the $\mathrm{Ni}_{1-x} \mathrm{Mg}_{x} \mathrm{O}$ film, i.e., the bandgap of the $\mathrm{Ni}_{1-x} \mathrm{Mg}_{x} \mathrm{O}$ thin film, was easily controlled by the $\mathrm{Mg}$ concentration of the precursor solution via mist CVD. In addition, the conductivity of $\mathrm{Ni}_{1-x} \mathrm{Mg}_{x} \mathrm{O}$ thin films was found to be controlled via Li-doping.

\section{EXPERIMENTAL DETAILS}

\section{Growth of Ni1-x $\mathrm{Mg}_{x} \mathrm{O}$ thin film}

Prior to the growth of $\mathrm{Ni}_{1-x} \mathrm{Mg}_{x} \mathrm{O}$, the $\alpha-\mathrm{Al}_{2} \mathrm{O}_{3}$ (0001) substrates were annealed in air at $1050{ }^{\circ} \mathrm{C}$ for $4 \mathrm{~h}$ to obtain an atomically flat surface and then sequentially cleaned in acetone, methanol, and deionized water using an ultrasonic cleaner. Undoped and Lidoped $\mathrm{Ni}_{1-x} \mathrm{Mg}_{x} \mathrm{O}$ thin films were grown via mist CVD; this procedure is described in detail in previous studies[1,7,8,11-13]. The growth conditions are summarized in Table I. In a previous study, nickel acetylacetonate $\left(\mathrm{Ni}(\mathrm{acac})_{2}\right.$ ) was used as a precursor for $\mathrm{NiO}$ thin films[7]. Similarly, the precursors used for the undoped $\mathrm{Ni}_{1-x} \mathrm{Mg}_{x} \mathrm{O}$ thin-film growth was $\mathrm{Ni}(\mathrm{acac})_{2}$ and magnesium acetylacetonate $\left(\mathrm{Mg}(\mathrm{acac})_{2}\right)$, which were diluted in deionized water at a total concentration of $0.020 \mathrm{~mol} / \mathrm{L}$. The Mg concentration in a source solution is determined from the ratio of the concentration of $\mathrm{Mg}(\mathrm{acac})_{2}$ to the concentration of $\mathrm{Mg}(\mathrm{acac})_{2}$ and $\mathrm{Ni}(\mathrm{acac})_{2}(\mathrm{Mg} /(\mathrm{Ni}+\mathrm{Mg}))$ and is expressed in at.\%. Following this, ethylenediamine (EDA) was added, which is a complex-forming additive. For Li-doped $\mathrm{Ni}_{1-x} \mathrm{Mg}_{x} \mathrm{O}$ thin films, the precursor solution was obtained by adding lithium acetylacetonate $(\mathrm{Li}(\mathrm{acac}))$ to the aqueous precursor solution containing $0.04 \mathrm{~mol} / \mathrm{L}$ $\mathrm{Ni}(\mathrm{acac})_{2}$ and $\left.0.16 \mathrm{~mol} / \mathrm{L} \mathrm{Mg(acac}\right)_{2}$. The Li concentration was varied from 0 to $2 \mathrm{mmol} / \mathrm{L}$ such that the Li concentration was $0-10$ mol.\% with respect to Ni plus Mg. Dry air was used for the carrier gas and dilution gases, with flow rates of 4.0 and $2.0 \mathrm{~L} / \mathrm{min}$, respectively. 
Table I. Growth conditions of $\mathrm{Ni}_{1-x} \mathrm{Mg}_{x} \mathrm{O}$ thin films.

$\begin{array}{lll}\text { Ni source, concentration } & \mathrm{Ni}(\text { acac })_{2}, 0-0.020 \mathrm{~mol} / \mathrm{L} & \text { Total concentration } \\ \text { Mg source, concentration } & \mathrm{Mg}(\text { acac })_{2}, 0-0.020 \mathrm{~mol} / \mathrm{L} & 0.020 \mathrm{~mol} / \mathrm{L} \\ \text { Complex agent, concentration } & \mathrm{EDA}, 0.040 \mathrm{~mol} / \mathrm{L} & \\ \text { Dopant, concentration } & \mathrm{Li}(\mathrm{acac}), 0-0.002 \mathrm{~mol} / \mathrm{L} & \\ \text { Solvent } & \text { Deionized water } & \\ \text { Carrier gas, flow rate } & \text { Dry air, } 4 \mathrm{~L} / \mathrm{min} & \\ \text { Dilution gas, flow rate } & \text { Dry air, } 2 \mathrm{~L} / \mathrm{min} \\ \text { Growth temperature } & 700{ }^{\circ} \mathrm{C} \\ \text { Growth time } & 10 \mathrm{~min} \\ \text { Substrate, size } & \alpha-\mathrm{Al}_{2} \mathrm{O}_{3}(0001), 10 \times 10 \mathrm{~mm} & \\ & & \end{array}$

\section{Characterizations}

To evaluate crystal structure, X-ray diffraction (XRD) analysis was performed using a Panalytical X'pert PRO MPD system. The composition of the films was determined via energy dispersive spectroscopy (EDS; INCAx-act, Oxford Instruments) and X-ray photoelectron spectroscopy (XPS; JPS-9030, JEOL). The surface morphology of the films was observed via atomic force microscopy (AFM) (SII Nano Technology, Nano Navi IIs Nanocute). UV-Vis spectral analysis was performed using a UV-Vis spectrophotometer (Shimadzu, UV-2450). The electrical resistivity of the films was determined via the four terminal method using a source measure unit (Keithley, 2450 SourceMeter); the film thickness was obtained from X-ray reflectivity measurements.

\section{RESULTS AND DISCUSSION}

Figure 1 shows the XRD patterns from the $2 \theta / \theta$ scan of $\mathrm{Ni}_{1-x} \mathrm{Mg}_{\mathrm{x}} \mathrm{O}$ thin films obtained from each $\mathrm{Mg}$ concentration precursor solution. Under all precursor solutions, diffraction peaks of $\mathrm{Ni}_{1-x} \mathrm{Mg}_{x} \mathrm{O}$ (111) and (222) were observed in addition to the diffraction peak of the $\alpha-\mathrm{Al}_{2} \mathrm{O}_{3}$ (0006) substrate. Figures 1 (b) and (c) show expanded $\mathrm{Ni}_{1-x} \mathrm{Mg}_{x} \mathrm{O}$ (111) and (222) diffraction peaks. Under the precursor solution containing a Mg concentration of $50 \%$ or less, Laue fringes were observed, suggesting that the $\mathrm{Ni}_{1-x} \mathrm{Mg}_{x} \mathrm{O}$ thin film was of high quality. As the Mg concentration in the precursor solution increased, the diffraction peak of $\mathrm{Ni}_{1-x} \mathrm{Mg}_{x} \mathrm{O}$ (111) and (222) shifted from the diffraction position of bulk $\mathrm{NiO}$ to that of bulk MgO. This result suggests that the $\mathrm{Mg}$ composition in the $\mathrm{Ni}_{1-x} \mathrm{Mg}_{x} \mathrm{O}$ thin film can be controlled by the $\mathrm{Mg}$ concentration of the precursor solution. Figure 2 shows a pole figure of the $\mathrm{Ni}_{1-x} \mathrm{Mg}_{x} \mathrm{O}$ thin film obtained from the source solution with a $\mathrm{Mg}$ concentration of $50 \%$. Similar pole figures were observed for all $\mathrm{Ni}_{1-x} \mathrm{Mg}_{x} \mathrm{O}$ thin films obtained from all $\mathrm{Mg}$ concentrations. Based on the XRD and X-ray pole figure measurements, the epitaxial relationships between $\mathrm{Ni}_{1-x} \mathrm{Mg}_{x} \mathrm{O}$ and $\alpha-\mathrm{Al}_{2} \mathrm{O}_{3}$ can be written as $\quad \mathrm{Ni}_{1-x} \mathrm{Mg}_{x} \mathrm{O}(111)[\overline{1} 10] \| \alpha-\mathrm{Al}_{2} \mathrm{O}_{3}(0001)[01 \overline{1} 0]$ and $\mathrm{Ni}_{1-x} \mathrm{Mg}_{x} \mathrm{O}$ (111)[110] $\| \alpha-$ $\mathrm{Al}_{2} \mathrm{O}_{3}(0001)$ [0110], similar to that described in a previous study on $\mathrm{NiO}$ [7].

Figure 3 shows the dependence of the $\mathrm{Mg}$ composition of the $\mathrm{Ni}_{1-x} \mathrm{Mg}_{x} \mathrm{O}$ thin film on the $\mathrm{Mg}$ concentration in the precursor solution. Both compositions are expressed in at.\% and calculated as $\mathrm{Mg} /(\mathrm{Mg}+\mathrm{Ni})$. As suggested by the XRD analysis, the $\mathrm{Mg}$ composition in the $\mathrm{Ni}_{1-x} \mathrm{Mg}_{x} \mathrm{O}$ film monotonously increases as the $\mathrm{Mg}$ concentration of the precursor solution increases. The Mg composition in the $\mathrm{Ni}_{1-x} \mathrm{Mg}_{x} \mathrm{O}$ thin film can be easily controlled by controlling the $\mathrm{Mg}$ and $\mathrm{Ni}$ concentration of the precursor solution. Even when the $\mathrm{Mg}$ concentration in the precursor solution reached $90 \%$, the $\mathrm{Mg}$ composition in the $\mathrm{Ni}_{1-x} \mathrm{Mg}_{x} \mathrm{O}$ 
thin film remained below 30\%. Because the growth conditions were optimized with $\mathrm{NiO}$, the reaction efficiency of the $\mathrm{Mg}$ precursor and the uptake efficiency of $\mathrm{Mg}$ may be low. Re-examining the growth conditions may generate a $\mathrm{Ni}_{1-x} \mathrm{Mg}_{x} \mathrm{O}$ thin film with higher $\mathrm{Mg}$ composition.
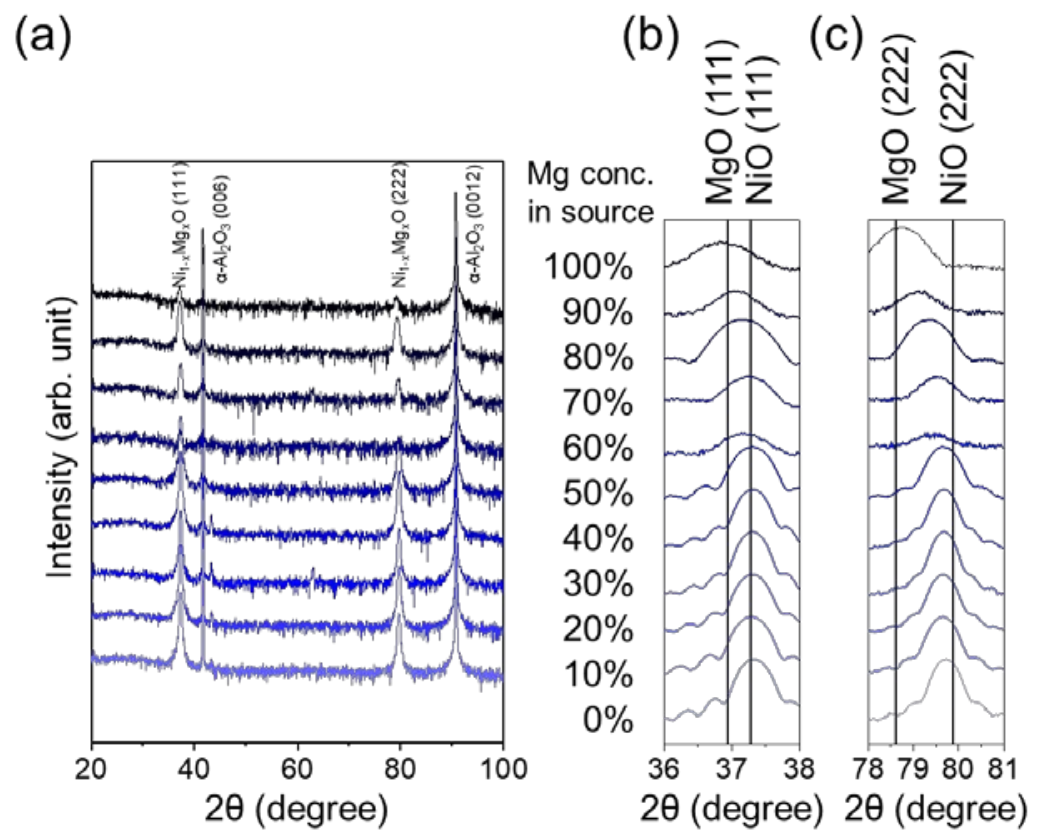

Figure 1. (a) X-ray diffraction patterns from the $2 \theta / \theta$ scan of the $\mathrm{Ni}_{1-x} \mathrm{Mg}_{x} \mathrm{O}$ thin films obtained from each $\mathrm{Mg}$ concentration precursor solution. Expanded views of the (b) $\mathrm{Ni}_{1-x} \mathrm{Mg}_{x} \mathrm{O}$ (111) and (c) (222) diffraction peaks.

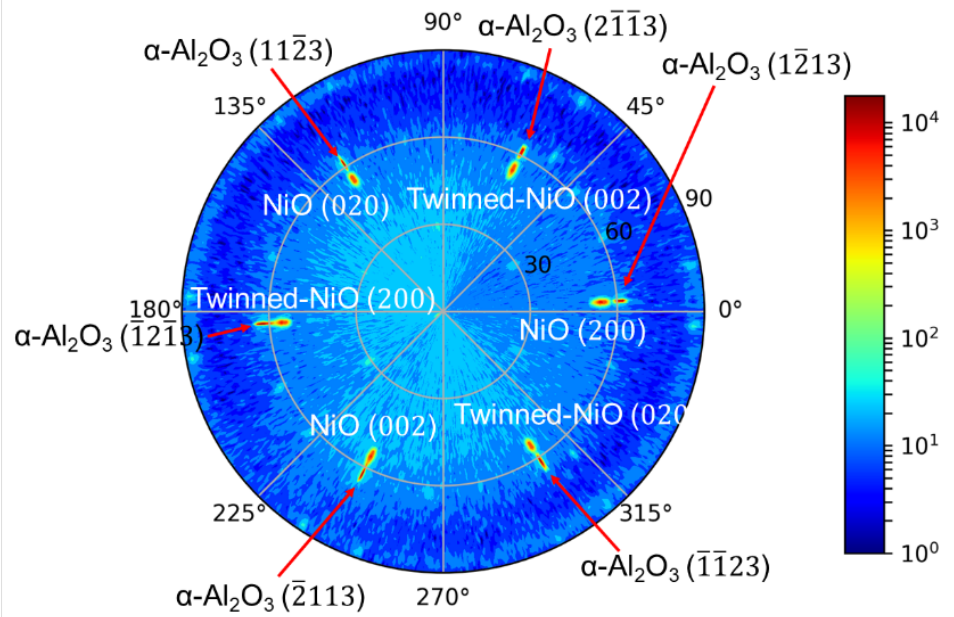




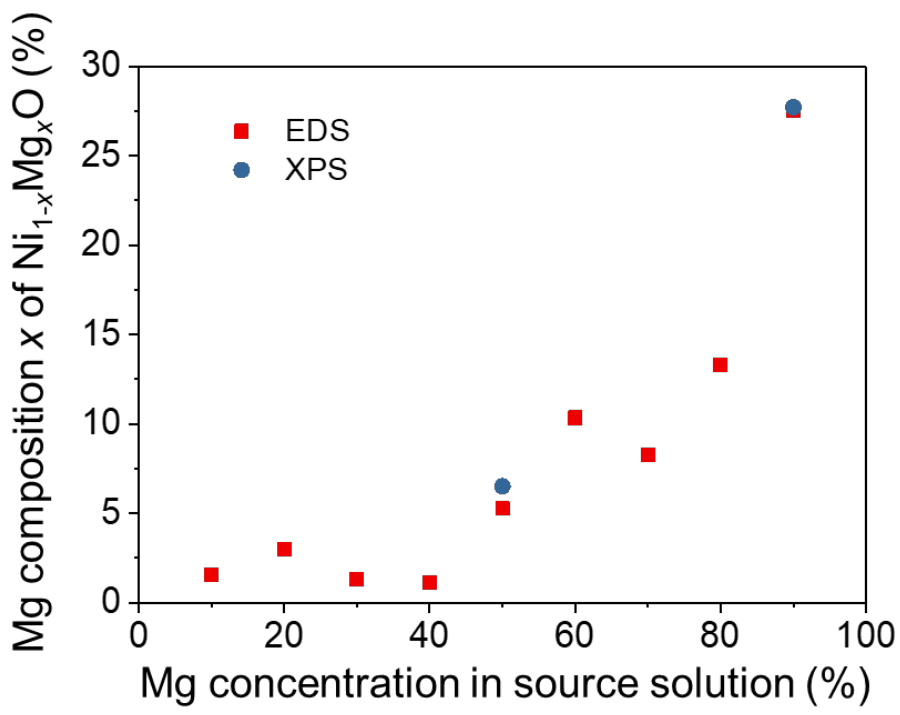

Figure 3. Dependence of the $\mathrm{Mg}$ composition of the $\mathrm{Ni}_{1-x} \mathrm{Mg}_{x} \mathrm{O}$ thin film on the $\mathrm{Mg}$ concentration in the precursor solution.

The surface morphology of the $\mathrm{Ni}_{1-x} \mathrm{Mg}_{x} \mathrm{O}$ thin film was investigated using AFM. The typical AFM image of the $\mathrm{Ni}_{1-x} \mathrm{Mg}_{x} \mathrm{O}$ thin film obtained from the source solution with a $\mathrm{Mg}$ concentration of $50 \%$ (Fig. 4) shows that the film is composed of crystal grains in the range of 100-300 $\mathrm{nm}$, which are derived from the domain structure.

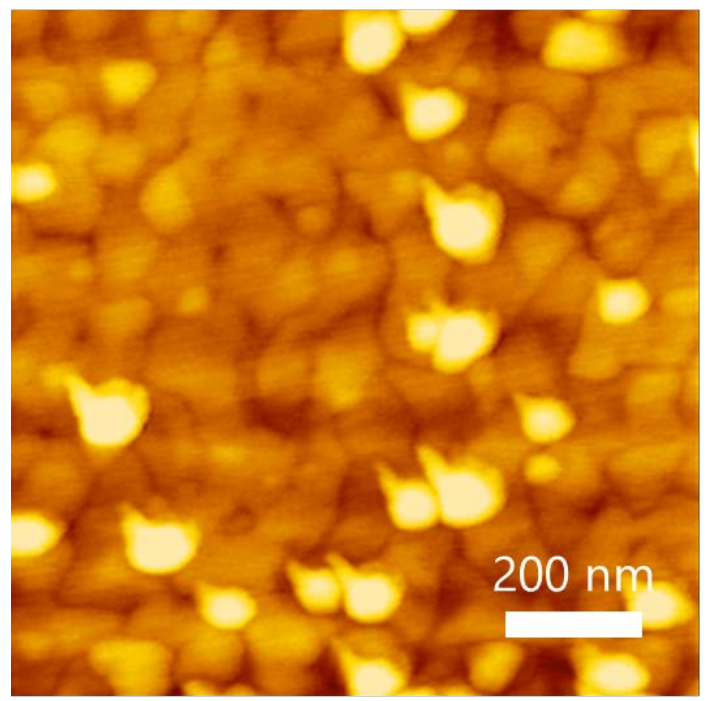


Figure 5 shows the transmittance spectra and Tauc plot of the $\mathrm{Ni}_{1-x} \mathrm{Mg}_{x} \mathrm{O}$ thin films with various $\mathrm{Mg}$ compositions. In the transmittance spectra, a marked decrease in the transmission rate occurred at wavelengths ranging from 350 to $300 \mathrm{~nm}$ depending on $\mathrm{Mg}$ composition, which is clearly due to absorption by $\mathrm{Ni}_{1-x} \mathrm{Mg}_{x} \mathrm{O}$. The bandgaps calculated from the Tauc plot $\left[(\alpha \mathrm{h} v)^{2}-\mathrm{h} v\right]$ also increased from $3.5 \mathrm{eV}$ to $3.9 \mathrm{eV}$ depending on the $\mathrm{Mg}$ composition. Figure 4 shows the composition dependence of the $\mathrm{Ni}_{1-x} \mathrm{Mg}_{x} \mathrm{O}$ thin film bandgap as calculated from the Tauc plot in this work (large red square). The bandgaps of $\mathrm{Ni}_{1-x} \mathrm{Mg}_{x} \mathrm{O}$ thin films in previous reports grown by the various methods[4,6,14-16] are also shown for comparison. The bandgaps observed herein have the same tendency as those of previous studies[17]: the bandgap increases with increasing $\mathrm{Mg}$ composition. The bandgap reached $3.9 \mathrm{eV}$ with a $\mathrm{Ni}_{1-x} \mathrm{Mg}_{x} \mathrm{O}$ thin film with $x=0.28$.

(a)

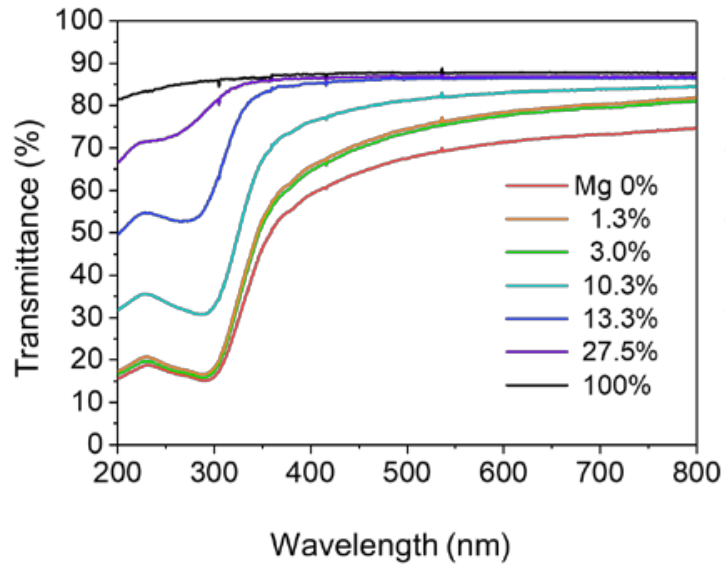

(b)

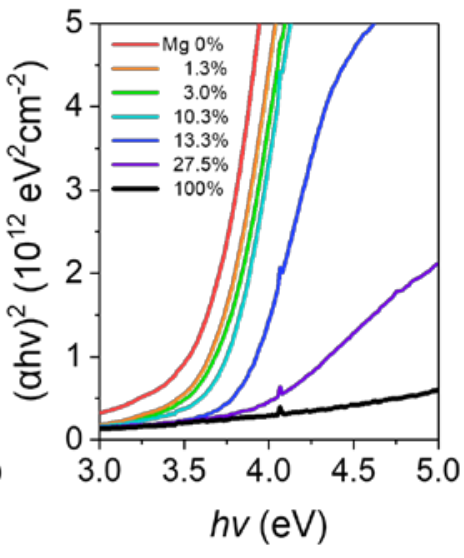

Figure 5. (a) Transmittance spectra and (b) Tauc plot of the $\mathrm{Ni}_{1-x} \mathrm{Mg}_{x} \mathrm{O}$ thin films.

Finally, conductivity control via Li-doping was investigated. For Li-doping, a precursor solution having a Mg concentration of $80 \%$ and a Ni concentration of $20 \%$ was used. The $\mathrm{Ni}_{1-x} \mathrm{Mg}_{x} \mathrm{O}$ thin film obtained using this precursor solution has a $\mathrm{Mg}$ composition of $13.3 \%$ and a bandgap of $3.8 \mathrm{eV}$. The same crystal structure, epitaxial orientation relationship, and optical properties as the undoped $\mathrm{Ni}_{1-x} \mathrm{Mg}_{x} \mathrm{O}$ thin film as described above were obtained for the Li-doped $\mathrm{Ni}_{1-x} \mathrm{Mg}_{x} \mathrm{O}$ thin films. Figure 6 shows the dependence of the Li-doped $\mathrm{Ni}_{1-x} \mathrm{Mg}_{x} \mathrm{O}$ thin film resistivity on Li concentration. As the $\mathrm{Li}$ concentration in the precursor solution increased, the resistivity value of the $\mathrm{Li}$-doped $\mathrm{Ni}_{1-x} \mathrm{Mg}_{x} \mathrm{O}$ thin film decreased. Furthermore, they exhibited positive Seebeck coefficients, indicating their p-type conductivity. When the Li concentration was $10 \%$, the resistivity was $43 \Omega \mathrm{cm}$. This variation in resistivity demonstrates the same tendency as that of $\mathrm{Li}$-doping in the $\mathrm{NiO}$ thin film on $\alpha-\mathrm{Al}_{2} \mathrm{O}_{3}$ [7], suggesting that both the increase in bandgap and p-type conductivity control were realized. 


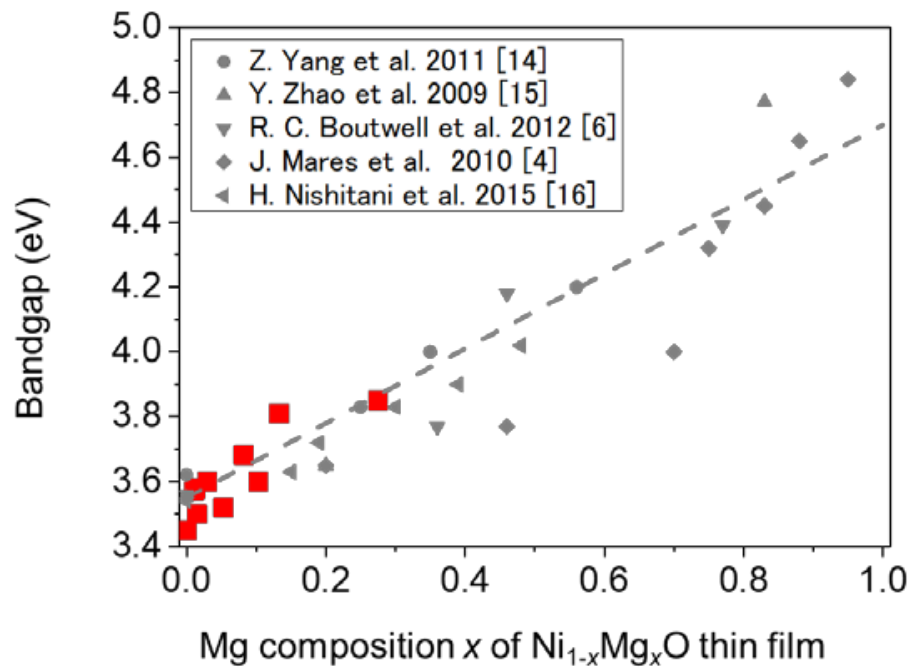

Figure 6. Dependence of the bandgap of the $\mathrm{Ni}_{1-x} \mathrm{Mg}_{\gamma} \mathrm{O}$ thin film on $\mathrm{Mg}$ composition.

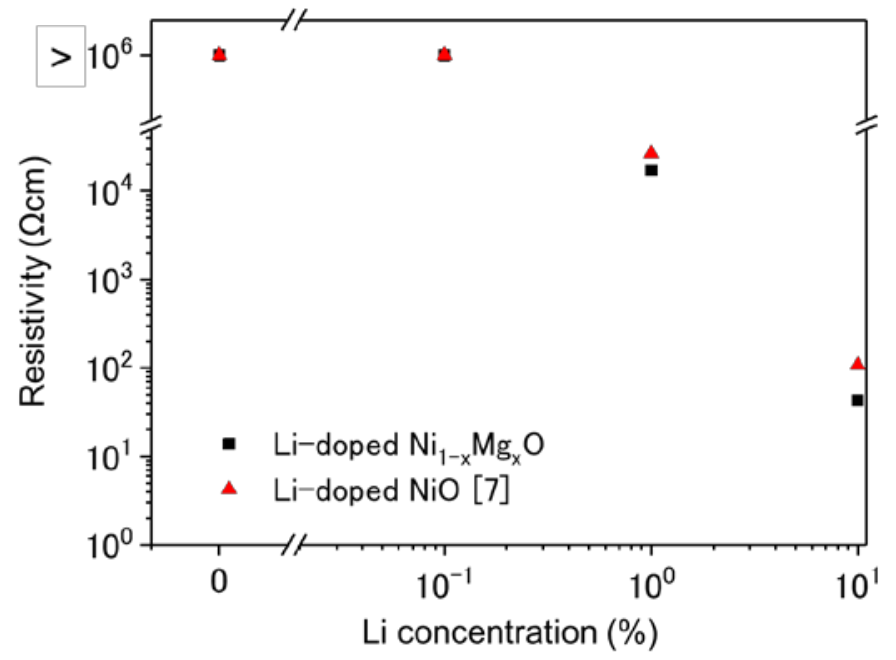

Figure 7. Dependence of the $\mathrm{Li}$ concentration on the resistivity of the $\mathrm{Li}$-doped $\mathrm{Ni}_{1-x} \mathrm{Mg}_{x} \mathrm{O}$ thin film.

\section{CONCLUSIONS}

In this study, $\mathrm{Ni}_{1-x} \mathrm{Mg}_{x} \mathrm{O}$ thin films were epitaxially grown on $\alpha-\mathrm{Al}_{2} \mathrm{O}_{3}$ substrates via mist CVD. The bandgap of $\mathrm{Ni}_{1-x} \mathrm{Mg}_{x} \mathrm{O}$ thin films increased depending on the $\mathrm{Mg}$ composition in the $\mathrm{Ni}_{1-x} \mathrm{Mg}_{x} \mathrm{O}$ thin film, which can be controlled by the $\mathrm{Mg}$ concentration in the precursor solution. The electrical resistivity of the $\mathrm{Ni}_{1-x} \mathrm{Mg}_{x} \mathrm{O}$ thin film, which was higher than $10^{6} \Omega \mathrm{cm}$ in the undoped sample, was improved to $10^{1}-10^{5} \Omega \mathrm{cm}$ via Li-doping, indicating that $\mathrm{Li}$ can be effectively doped into $\mathrm{Ni}_{1-x} \mathrm{Mg}_{x} \mathrm{O}$ thin films. 


\section{ACKNOWLEDGMENTS}

This study was supported by Japan Society for Promotion of Science EarlyCareer Scientists (grant No. JP18K13788) and Grant-in-Aid for Scientific Research (C) (grant No. 20K04580).

\section{References:}

[1] D. Shinohara and S. Fujita, Jpn. J. Appl. Phys. 47, 7311-7313 (2008). doi:10.1143/JJAP.47.7311.

[2] A. Kuzmin and N. Mironova, J. Phys. Condens. Matter. 10, 7937-7944 (1998). doi:10.1088/0953-8984/10/36/004.

[3] D.M. Roessler and W.C. Walker, Phys. Rev. 159, 733-738 (1967). doi:10.1103/PhysRev.159.733.

[4] J.W. Mares, C.R. Boutwell, A. Scheurer, M. Falanga and W. V. Schoenfeld, Proc. SPIE 7603, 76031B (2010). doi:10.1117/12.841327.

[5] Y.M. Guo, L.P. Zhu, J. Jiang, L. Hu, C.L. Ye and Z.Z. Ye, Appl. Phys. Lett. 101, 052109 (2012). doi:10.1063/1.4742172.

[6] R.C. Boutwell, M. Wei, A. Scheurer, J.W. Mares and W.V. Schoenfeld, Thin Solid Films 520, 4302-4304 (2012). doi:10.1016/j.tsf.2012.02.065.

[7] T. Ikenoue, J. Inoue, M. Miyake and T. Hirato, J. Cryst. Growth. 507, 379-383 (2019). doi:10.1016/j.jcrysgro.2018.11.032.

[8] H. Nishinaka, Y. Kamada, N. Kameyama and S. Fujita, Phys. Status Solidi. 247, 1460-1463 (2010). doi:10.1002/pssb.200983247.

[9] K. Kaneko, T. Onuma, K. Tsumura, T. Uchida, R. Jinno, T. Yamaguchi, T. Honda and S. Fujita, Appl. Phys. Express 9, 111102 (2016). doi:10.7567/APEX.9.111102.

[10] H. Ito, K. Kaneko and S. Fujita, Jpn. J. Appl. Phys. 51, 100207 (2012). doi:10.1143/JJAP.51.100207.

[11] H. Nishinaka, Y. Kamada, N. Kameyama and S. Fujita, Jpn. J. Appl. Phys. 48, 121103 (2009). doi:10.1143/JJAP.48.121103.

[12] K. Akaiwa and S. Fujita, Jpn. J. Appl. Phys. 51, 070203 (2012). doi:10.1143/JJAP.51.070203.

[13] N. Suzuki, K. Kaneko and S. Fujita, J. Cryst. Growth. 364, 30-33 (2013). doi:10.1016/j.jcrysgro.2012.11.065.

[14] Z.-G. Yang, L.-P. Zhu, Y.-M. Guo, Z.-Z. Ye and B.-H. Zhao, Thin Solid Films 519, 5174-5177 (2011). doi:10.1016/j.tsf.2011.01.082.

[15] Y. Zhao, J. Zhang, D. Jiang, C. Shan, Z. Zhang, B. Yao, D. Zhao and D. Shen, J. Phys. D. Appl. Phys. 42, 092007 (2009). doi:10.1088/0022-3727/42/9/092007.

[16] H. Nishitani, K. Ohta, S. Kitano, R. Hamano, M. Inada, T. Shimizu, S. Shingubara, H. Kozuka and T. Saitoh, Appl. Phys. Express 9, 039201 (2016). doi:10.7567/APEX.9.039201.

[17] C.A. Niedermeier, M. Råsander, S. Rhode, V. Kachkanov, B. Zou, N. Alford and M.A. Moram, Sci. Rep. 6, 31230 (2016). doi:10.1038/srep31230. 